\title{
E-GOVERNMENT IMPLEMENTATION
}

\author{
Phonepaseuth Solinthone ${ }^{1,2 a}$, Tatyana Rumyantseva ${ }^{1}$ \\ ${ }^{1}$ National Research Tomsk State University, 634050, Tomsk, Russia \\ ${ }^{2}$ Ministry of Science and Technology, 2279, Lao PDR
}

\begin{abstract}
Information and communication technologies (ICTs) are playing an increasingly vital role in the daily lives of people, revolutionizing work and leisure and changing the rules of doing business. In the realm of government, ICT applications are promising to enhance the delivery of public goods and services to citizens not only by improving the process and management of government, but also by redefining the traditional concepts of citizenship and democracy. The ICTs' effect on societies are both far-reaching and uneven. On the one hand, ICT is fueling the transition from industrial-based economies to knowledge-based societies. On the other hand, ICT still has little or no impact in the lives of people in many countries. This wide disparity in the impact of ICT around the world today underscores the uneven progress of economic development. It also highlights the critical role of government in the information age. The goal of this article is to provide a brief overview of E-government studies and their evaluation, to clarify the major issues, which can make E-government to be more effective, transparent and responsive. The article considers the significance of contemporary E-government activity.
\end{abstract}

\section{What is e-government?}

Definitions of E-government range from "the use of information technology to free movement of information to overcome the physical bounds of traditional paper and physical based systems" to "the use of technology to enhance the access to and delivery of government services to benefit citizens, business partners and employees." The common theme behind these definitions is that E-government involves the automation or computerization of existing paper-based procedures that will prompt new styles of leadership, new ways of debating and deciding strategies, new ways of transacting business, new ways of listening to citizens and communities, and new ways of organizing and delivering information [1].

Ultimately, E-government aims to enhance access to and delivery of government services to benefit citizens. More important, it aims to help strengthen government's drive toward effective governance and increased transparency to better managing country's social and economic resources for development.

The key to E-government is establishment of a long-term, organization-wide strategy to constant improvement of operations with the view of fulfilling citizen needs by

\footnotetext{
${ }^{\text {a }}$ Corresponding author: phonepaseuth.slt@gmail.com
} 
transforming internal operations such as staffing, technology, processes and workflow management.

\subsection{What are the types of E-government transactions?}

E-government services focus on four main customers: citizens, business community, government employees, and government agencies. E-government aims to make interaction with citizens, businesses, government employees, government agencies and other governments more convenient, friendly, transparent, inexpensive and effective.

In an E-government system, individuals are able to initiate a request for a particular government service and then receive that government service through the Internet or some computerized mechanism. In some cases, the government service is delivered through one government office, instead of many. In other cases, a government transaction is completed without direct in-person contact with a government employee.

\subsection{What are the specific types of services types of E-government?}

There are four types of E-government services:

- Government-to-Citizen (G2C).

- Government-to-Business (G2B).

- Government-to-Employee (G2E).

- Government-to-Government (G2G).

\subsubsection{Government-to-citizen}

G2C includes information dissemination to the public, basic citizen services such as license renewals, ordering of birth/death/marriage certificates and filing of income taxes, as well as citizen assistance for such basic services as education, health care, hospital information, libraries, and the like.

Case 1. Singapore's E-citizen Portal: A Case Study in G2C Transactions

Through Singapore's E-citizen portal, Singaporeans are able to access about 1,600 Eservices pertaining to business, health, education, recreation, employment, and family. Of this, 1,300 E-services are completely transacted by citizens with government online. The Ecitizen portal is divided into categories based on the real-life needs of every individual, with every single ministry and statutory board providing E-services through the same portal. Singaporeans thus have one-stop access to government services; they are spared having to navigate through the bureaucratic jungle. A few of the popular E-services are the following: submitting application forms for purchase of apartments, searching for school information, employment search, career development, and voter registration. As of June 2002, about $77 \%$ of public services deemed feasible for E-delivery were enabled for online delivery [2].

\subsubsection{Government-to-business}

G2B transactions include various services exchanged between government and the business community, including dissemination of policies, memos, rules and regulations. Business services offered include obtaining current business information, downloading application forms, renewing licenses, registering businesses, obtaining permits, and payment of taxes. The services offered through G2B transactions also assist in business development, specifically the development of small and medium enterprises (SME). Simplifying 
application procedures that would facilitate the approval process for SME requests would encourage business development.

On a higher level, G2B services include E-procurement, online government-supplier exchange for the purchase of goods and services by government. Typically, E-procurement Web sites allow qualified and registered users to look for buyers or sellers of goods and services. Depending on the approach, buyers or sellers may specify prices or invite bids. Eprocurement makes the bidding process transparent and enables smaller businesses to bid for big government procurement projects. The system also helps government generate bigger savings, as costs from middlemen are shaved off and purchasing agents' overhead is reduced.

\subsubsection{Government-to-employee}

G2E services encompass G2C services as well as specialized services that cover only government employees, such as the provision of human resource training and development that improve the bureaucracy's day-to-day functions and dealings with citizens.

\subsubsection{Government-to-government}

G2G services take place at two levels: at the local or domestic level and at the international level. G2G services are transactions between the central/national and local governments, and between department-level and attached agencies and bureaus. At the same time, G2G services are transactions between governments, and can be used as an instrument of international relations and diplomacy.

\section{The goals of E-government}

\subsection{What are the goals of E-government?}

The Working Group on E-government in the developing world has identified five broad categories of goals commonly pursued for E-government. E-government is a means to accomplish these broader social goals, goals that move beyond mere efficiency of government processes to that of overall reform and development. The goals are not listed in any particular order of importance, as each country must determine its priorities in Egovernment.

1. Creating a better business environment.

2. Customers online, not in line.

3. Strengthening good governance and broadening public participation.

4. Improving the productivity and efficiency of government agencies.

5. Improving the quality of life for disadvantaged communities.

\section{E-government and human development}

\subsection{How do ICTs facilitate good governance?}

ICT is an enabler of efficient and effective function of government. In turn, more efficient government function enables improved and better governance. 
The Cristal Web site was specifically created to fulfill the mandate of a law that requires that the state makes available "to whatever institution or interested person" the following information related to the administration of public funds:

- Execution of budgets, to the lowest level of disaggregation.

- Purchase orders and public contracts.

- Financial and employment data concerning permanent and contracted staff.

- An account of the public debt, including terms, guarantees, interest costs, etc.; outstanding tax and customs obligations of Argentine companies and people.

- Regulations governing the provision of public services.

- All information necessary for the community control of social expenditures.

A primary goal of the Cristal program is to create a better-informed citizenry that can provide control over political representatives more effectively. While the content of the Web site is directed to all citizens, journalists are particularly important audience of the site, as newspapers and television enable much wider dissemination of its contents.

\subsection{What are the implications of equality of access to government information and services?}

The implementation of E-government facilitates citizen participation in governance by increasing access channels to government. It broadens opportunities for citizen participation, opening new channels of communication between constituents and their representatives and bringing marginal groups (i.e., women, physically challenged, indigenous peoples) into mainstream participatory channels.

However, as E-government initiatives have the potential to democratize the delivery of basic services and "level" the effects of development, these same initiatives can also further citizens distance from government and even deepen existing disenfranchisement. Policymakers, in trying to achieve development goals through E-government, should consider projects that would deliver the most benefits to the broadest number of people.

\subsection{What is digital democracy?}

Digital democracy is a term used when the use of information and communications technology enhances citizen participation in the democratic process. It is the computerization of political discourse, policy-making and the political process with the end in view of increasing, enhancing, and deepening citizen participation in the policy- and decision-making processes of government through a spectrum of activities: electoral campaigns, voting, consultation and participation in the policy process, public opinion polling, and communication exchange between elected officials and constituents.

While opportunities are increasing for citizens to be more actively involved in the policy-making and decision-making process, much of government decision-making is still hidden from the wider public. ICT integration in government processes facilitates greater openness, transparency, and accountability. As more information is given to the public, greater citizen engagement in the overall policy process is considered as necessary as greater accountability for public officials.

Case 2. Improving Service Delivery To Women Through ICT: The Women's Services Portal in British Columbia, Canada

To improve service delivery to women, the Government of British Columbia has created a portal dedicated to delivering services for women. The women's services site [3] is embedded within the British Columbia government portal called "BC Connects" [4].

This Web site provides information, government assistance and training to women in general, as well as to aboriginal, immigrant and minority women living in the province of 
British Columbia. The services include application for business loans and childcare subsidy, employment preparation training, job matching, health information services, and counseling and legal aid.

\section{Advantages and disadvantages and the challenges of E- government implementation}

\subsection{Advantages of E-government}

Advantages and benefits of E-government implementation are the same for both developed and developing countries. However, E-government applications have many benefits for citizens, business and government entities. E-government applications allow people, businesses, and government sectors to access to available government information 24 hours a day, 7 days a week, which improves the quality of these services. Implementation of Egovernment can reduce cost and levels of organizational processes by streamlining and reorganizing operating procedures. Moreover, use of E-government systems can improve the performance of government agencies because they will be able to deliver the public service effectively and efficiently for all customers. In addition, E-government has great benefits regarding economizing and improving of governments' service operations, including efficiency, reduced transactional costs, increase the transparency and increased services for citizens. Furthermore, we can identify E-government benefits as follows:

- Reduction of customers' and organizations' time, effort and costs.

- Improvement of service delivery and citizens' satisfaction.

- Increase of users' ICT skills, internet knowledge and computer usage.

- Creation of new business and work opportunities.

In addition, E-government implementation has many advantages such as:

- Improvement of efficiency of government agencies in data processing.

- Improvement of services through better understanding of users' requirements, thus aiming for seamless online services.

- Sharing information and ideas between all government agencies and department to build one mega database.

- Assisting in reaching government's economic policy objectives by promoting productivity gains inherent in ICT and e-commerce.

- Improvement of transparency, accuracy and facilitating information transfer between government and customers.

- Assisting in building trust between governments and citizens.

- Essential factor in good governance by using internet-based strategies to involve citizens in the policy process, illustrating government transparency and accountability.

To conclude, it is clear that implementation of E-government saves resources, effort and money but it can also extensively increase service quality levels and reduce time spent in government departments. [5]

\subsection{Disadvantages of E-government}

In spite of some advantages gathered from successful E-government implementation, there are also some disadvantages. Some of these disadvantages are briefly discussed in this paper below and include lack of equality in public access to the Internet, lack of trust and cyber-crime, hyper- surveillance, false sense of transparency and accountability and costly infrastructure. 


\subsubsection{Lack of equality in public access to the Internet}

Studies have shown that there is potential for reduction in the usability of government online due to factors such as the access to Internet technology and usability of services and the ability to access to computers (MSG, 2008), plus literacy of the users and the ability to use the computer.

There are users who are illiterate (do not know how to read and write), who would need assistance. An example would be the elderly (senior citizens). Generally, senior citizens do not have much education and they would have to approach a customer service officer for assistance. Bwalya et. al. echoes the same sentiments that some of the disadvantages of Egovernment implementation could be the likelihood of excluding citizens and businesses that have no access to technology due to the digital divide (e-exclusion).

\subsubsection{Lack of trust and cyber crime}

Even though the level of confidence in the security offered by government web sites are high, the public are still concerned over security, fear of spam from providing email addresses, and government retention of transaction or interaction history. Similarly, Varros posits this too that, despite the efforts of government agencies to ensure the safety of citizen's personal data, E-governance websites are still liable to attack from hackers. Personal data can be exposed and there is less trust to how the information is kept secure and whose hands it lands on. This is also pointed out by Bwalya et. al. (2012), that one of the disadvantages could be generally a lack of engagement due to the anticipated low levels of trust by citizens of the E-government platforms.

\subsubsection{Hyper surveillance}

Sharma, Bao and Qian [6] hints that even though developing countries attempt to improve public services through E-government implementation, they also turn to increase control over people through E-government. Augmented contact between government and its citizens is bi- directional (it goes both ways).

Once E-government starts to develop and become more sophisticated, citizens will be forced to interact electronically with the government on a larger scale. This could potentially lead to a lack of privacy for civilians as their government obtains more and more information on them. There are very real concerns about turning over much information to the government by the citizens or businesses. While the government may see like a benevolent organization, it is possible this may not be true in the future or that outside governments/or parties could use this information to harm the citizens of this country and the businesses.

\subsubsection{False sense of transparency and accountability}

Those against E-government argue that online governmental transparency is dubious because the governments themselves maintain it. Information can be added or removed from the public eye. To this day, very few organizations monitor and provide accountability for these modifications. Majozi (2008) also highlights that hidden agendas of government groups that could influence and bias public opinions are among disadvantages of Egovernment implementation. 


\subsubsection{Costly Infrastructure}

According to Vassos [7], an efficient E-government system requires all citizens or at least the vast majority to have access to the Internet. Therefore, Internet-enabled devices, hardware such as routers, and connection infrastructure are essential to connect to government websites.

Additionally, public sector agencies need advanced servers and security systems to cope with vast amounts of information and fire walls for complex cyber threats. All these requirements constitute a costly investment, far beyond the reach of less developed economies.

Ngulube [8] concurs to this that one of the disadvantages of E-government implementation is technological costs. The costs include infrastructure development, interoperability of the technologies, permanent availability and preservation, education and training of operating and using the technology, cost structures and benchmarking. The cost cannot only be disadvantageous to the government, but also to the citizens and the businesses who cannot afford.

\subsection{The Challenges of E-government}

\subsubsection{Who pays for E-government?}

Like any government infrastructure project, E-government can be done in phases and the costs of implementation will depend on current infrastructure availability, supplier and user capabilities, and mode of service delivery (whether through the Internet or through telephone hotlines and one-stop shops). The more complicated and sophisticated the kind of services the government wants to offer, the more expensive it is. [9]

Governments should focus on small, self-financing or outsourced projects. Because Egovernment projects must be financially sustainable, there must be a revenue/ costreduction model in place from the beginning. Smaller projects with a clear revenuegeneration strategy and minimal initial investment are the most likely to be sustainable over the long term. For instance, web sites are one of the easiest and cheapest ways to achieve high impact E-government with a minimum of investment.

E-government projects are, more often than not, long-term endeavors, requiring large capital infusion in software, hardware, infrastructure and training. A viable financing plan should not only pay for the immediate needs to jumpstart E-government; it must also consider its long-term financing options for the sustainability of the project.

There are various business models for funding E-government projects, and the private sector plays a critical role in these. Under partnership arrangements, the private sector builds, finances and operates public infrastructure such as roads and airports, recovering costs through user charges. Various financing schemes exist from soft and development assistance loans from donor/multilateral aid agencies to partnerships and outsourcing deals with private third party vendors under special financing schemes (e.g., the Build-OperateTransfer or BOT scheme) that can minimize the initial cost to government.

BOT and its variants are usually the favored financing models/arrangements for government projects that require large and immediate financing from the private sector. Under BOT, the private sector designs, finances, builds, and operates the facility over the life of the contract. At the end of this period, ownership reverts to the government. A variation of this is the Build-Transfer-Operate (BTO) model, under which title transfers to the government when construction is completed. Finally, with Build-Own-Operate (BOO) arrangements, the private sector retains permanent ownership and operates the facility on contract. 
Cooperation, rather than competition, with the private sector can facilitate effective Egovernment. Government can encourage private sector investment by complementing and supporting private sector efforts rather than duplicating them. The key to E-government is to improve citizen access to service delivery, not expand the role of government. Government should not attempt to create products, services where public-private partnerships or private service providers can adequately provide these products, and services more efficiently and effectively.

\subsubsection{How do you get the wider public to use E-government services?}

Any E-government policy must consider a citizen-centered approach. This means that Egovernment should be an end-user or demand-driven service. However, many citizens do not use e-government for several reasons, among these unfamiliarity with ICT, lack of access, lack of training, and concerns about privacy and security of information. While Egovernment may provide ease and convenience in the delivery of public services, and offer innovative government services, none of these will prompt citizen use unless the concerns mentioned above are resolved.

\subsubsection{Why are security and protection of privacy important?}

Security generally refers to the protection of information system assets and control of access to information. Security policies and strategies are context- and information-specific.

Privacy refers to the right for information attributed to an individual (also called "nominal information") to be treated with an appropriate level of protection. Information privacy protection laws are often put in place to regulate this.

Protecting the privacy of citizens and assuring them that their personal information will not be compromised is critical in E-government because this is the key to user trust. Without this assurance, no one will use E-government services.

\section{An overview of the 2014 united nations E-government survey}

The Department of Economic and Social Affairs produce the United Nations E-government Survey every two years. It is the only report in the world that assesses the E-government development status of the 193 United Nations Member States. It serves as a tool for decision-makers to identify their areas of strength and challenges in E-government and to guide E-government policies and strategies. The publication also highlights emerging Egovernment trends, issues and innovative practices, as well as challenges and opportunities of E-government development. Each chapter provides an analysis of the Survey's data, as well as highlights strategies, challenges and opportunities. The Survey is intended for government officials, academics, intergovernmental institutions, civil society organizations, the private sector and citizens at large. Table 1 shows the E-government Development Index (EGDI) of the year 2014. [10]

Table 1. The E-government Development Index (EGDI) 2014. Top ten EGDI Rank with Russia Federation, China, Lao PDR .

\begin{tabular}{|c|c|c|}
\hline \multirow{2}{*}{ Rank } & Countries List & EGDI Percentage \\
\hline 1 & Republic of Korea & 0.946 \\
\hline 2 & Australia & 0.910 \\
\hline 3 & Singapore & 0.908 \\
\hline
\end{tabular}




\begin{tabular}{|c|c|c|}
\hline 4 & France & 0.894 \\
\hline 5 & Netherlands & 0.890 \\
\hline 6 & Japan & 0.887 \\
\hline 7 & United States of America & 0.875 \\
\hline 8 & United Kingdom & 0.870 \\
\hline 9 & New Zealand & 0.864 \\
\hline 10 & Finland & 0.845 \\
\hline 27 & Russian Federation & 0.730 \\
\hline 70 & China & 0.545 \\
\hline 152 & Lao People's Democratic Republic & 0.266 \\
\hline
\end{tabular}

\subsection{Case study of E-government of Korea}

- Korea has actively pursued E-government as a crucial means to make its government more competitive, by leveraging the world's best information and communications technology including broadband Internet.

- After laying the groundwork for E-government, including the National Basic Information System (NBIS) computer networks in the 1980s and streamlining of applicable laws and institutions in the 1990s, the Korean government made the implementation of Egovernment a major national agenda for the 2000s. It has concentrated on 11 major tasks for E-government (2001 2002) and 31 major tasks for the E-government roadmap (2003 2007). As a result, E-government has become firmly established in all areas of Korean government.

- Korean E-government has produced visible results: both efficiency and transparency of administrative work have been significantly improved; administrative civil services have been greatly enhanced; and opportunities for people to participate in the policy-making process have been expanded.

- Accordingly, the effectiveness of the E-government of Korea is widely acknowledged by the international community and various E-government systems are being exported to foreign countries. The 2010 UN Global E-government Survey shows that Korea is ranked first among all the member countries, given the highest possible scores in the categories of Online Service Index and the E-participation Index.

- Korea is now promoting E-government that is focusing on utilization and convergence by consolidating services to maximize the convenience of users and implementing a seamless digital cooperation system connecting government departments and agencies, in order to improve the overall quality [11].

\subsubsection{Achievements}

\section{A. Improvement of efficiency and transparency of administrative work}

- Use of electronic documents has become standard practice, and most administrative business such as personnel management, finance, and procurement are being handled electronically. This greatly and innovatively enhances the overall efficiency of government administration.

- All central administrative organizations have introduced a standardized business process system (On-nara) to record all decision-making procedures of the government, increasing transparency of administration significantly. 
B. Provision of people and company-focused administrative services

- The age of civil service processing at home has been fully ushered in by implementing integrated online civil service processing channels and enabling notification, filing, and payment of taxes via the Internet.

- Various corporate activities are supported efficiently by means of a single window for corporate support and processing of logistics, customs clearance, and trading online.

C. Strengthening of communications with the people about government policies

- People can now participate in the government decision-making process more easily through a single window linked to all administrative organizations that provides comprehensive civil services and receives public suggestions.

- People can request and check a wide range of administrative information online easily. It is possible to check national records anytime, anywhere.

D. Increased efficiency of information resource management

- The government's integrated computing center comprehensively manages all information systems of the government, improving its capability to respond to system errors and security threats.

- Introduction of Enterprise Architecture (EA), which acts as a comprehensive informatization blueprint enables systematic management of E-government.

\subsubsection{E-government Best Practices}

- Electronic Procurement Service (www.g2b.go.kr).

- Electronic Customs Clearance Service (portal.customs.go.kr).

- Comprehensive Tax Services (www.hometax.go.kr).

- Internet Civil Services (www.egov.go.kr).

- Patent Service (www.kiporo.go.kr).

- e-People: Online Petition \& Discussion Portal (www.epeople.go.kr).

- Single Window for Business Support Services (www.g4b.go.kr).

- On-nara Business Process System (BPS).

- Shared Use of Administrative Information (www.share.go.kr).

- National Computing \& Information Agency (NCIA).

\section{Conclusion of world E-government}

Public administration, being the cornerstone of governments' work is essential for improving peoples' lives. As illustrated in this chapter, amidst the economic, social and environmental challenges, E-government is continuing to play an important role in enabling the delivery of quality public services that meet citizen needs and goals by transforming how the public sector works.

Countries must decide the level and extent of their E-government initiatives based on their specific national development context.

In addition to effective planning and deployment of E-services, governments may consider enhancing their ICT infrastructure and raise the level of human capital, including improvement of the ICT literacy of citizens, to make use of the new technologies to realize the full benefits of online and mobile services. This should go hand in hand with capacity development of leadership in E-government and public servants as facilitators of online public services.

These countries are ahead, because as the world economy begins to recover from one of the worst economic crises in decades, information and communication technologies (ICT) is bound to play an increasingly prominent role as a key enabler of renewed and sustainable 
growth, given that it has become an essential element of the infrastructure underpinning competitive economies. ICT will continue spreading its revolutionary power to modernize economies and societies and improve living conditions and opportunities around the world.

ICT performance will remain crucial not only for developed countries for sustaining and enhancing their innovation potential and long-term competitiveness, but also for middleincome and developing countries in fostering structural transformations, increasing efficiency as well as reducing the digital, economic, and social divides within their territories and more advanced economies. If ICT plays a central role in ensuring economic sustainability, it can and must play an equally central role in promoting environmental and social sustainability, both as an industry and as a key element of enabling infrastructure. In mind opinion, I believe sustainability, in all its components, should be a priority for policymakers, businesses, and civil society alike to foster a more inclusive and crisisresilient world. ICT and the ICT industry must now rise to increase information of their countries, improve the quality of education, increase knowledge for their people, developments of economic, social, political, culture and improve management systems by using ICT.

\section{Acknowledgements}

The paper was written as part of the research project No. 8.2.31.2015, carried out with the support of the Program "Research Foundation of Tomsk State University named after D.I. Mendeleev" in 2015 - 2016., grant RFBR No. 16-29-12858.

\section{References}

[1] E-government wikibooks URL: https://en.wikibooks.org/wiki/E-government/

[2] Case 1. Singapore's e-citizen Portal URL: http://www.ecitizen.gov.sg

[3] Case 2.2 The women's services

URL: http://www.cserv.gov.bc.ca/womens_services/links/index.htm

[4] The British Columbia government portal site URL: http://www.gov.bc.ca

[5] S.R. Joseph, International journal of technology marketing 5(9), 18 (2015)

[6] G. Sharma, X. Bao, W. Qian, International Journal of Advanced Research in Computer Science and Software Engineering 2, 19 (2012)

[7] T. Vassos,Advantages and disadvantages of E-governance

URL: Available at http://www.ehow.com/info_8473642_advanta ges-disadvantages egovernance.html

[8] P. Ngulube, The Nature and Accessibility of E-government in Sub Saharan Africa. International Review of Information Ethics 7,1 (2007)

[9] M. Alshehri, S. Drew, Implementation of e-Government: advantages and challenges URL:

http://www98.griffith.edu.au/dspace/bitstream/handle/10072/40620/72631_1.pdf?se quence $=1$

[10] UN E-government Survey 2014

URL:https://publicadministration.un.org/egovkb/portals/egovkb/documents/un/2014

-survey/e-gov_complete_survey-2014.pdf

[11] Case Study of E-government of Korea

URL:

http://unpan1.un.org/intradoc/groups/public/documents/UNGC/UNPAN043625.pdf 